\title{
Re-mediating Ophelia with Pre-Raphaelite Eyes
}

\author{
SIMONETTA FALCHI
}

\begin{abstract}
The Shakespearean fair Ophelia has become through the centuries a multifaceted heroine apt to embody all the victims of patriarchal domination, but also the evil and victimized decadent lady, who would annihilate her tormentor. Similar oxymoronic identifications were possible partly because of the vagueness that distinguishes her character in the Shakespearean tragedy, and partly because of the fluctuating status of adolescent girls in society. Moreover, the contemporary reception of Ophelia has strongly been biased by the treatment of this literary myth by the Pre-Raphaelite Brotherhood. In the Victorian era, when issues about the condition, the power, and the rights of women were raised with particular force, Ophelia soon became an icon of sublime but dangerous beauty. Such an association even came to the point that Elizabeth Siddal - poet, painter, and model of Millais's Ophelia - was identified with the Shakespearean heroine, by virtue of her unquenchable thirst for knowledge, her unrequited love, her prettiness, and the torture she allegedly provoked to Dante Gabriel Rossetti’s conscience.
\end{abstract}

Keywords: John Everett Millais, Heiner Mueller, Ophelia, Pre-Raphaelitism, Rewriting of myth, Dante Gabriel Rossetti, Elizabeth Siddal

\section{Introduction: Reviving Ophelia}

The "young, the beautiful, the harmless and the pious" Ophelia (Johnson 1765: 311), generated by Shakespeare's great imagination, has drifted apart from her frail origins to turn, in the twentieth century, into a subversive heroine symbol of the victims of patriarchal domination (Showalter 1985) - and then again into the emblem of fragile adolescent girls in need of guidance, under the burden of societal pressure (Pipher 1994). This ability to adapt to the spirit of Time has rendered her the most represented of Shakespeare's heroines and "the most persistently presented in terms of symbolic meanings" (Gellert-Lyons 1977: 61).

Ophelia's myth (Solomon Kiefer 2001: 11) is nourished by her beauty, her youth, her madness, and her mysterious death. The Shakespearean text says little about her. However, although she only appears in five of the twenty scenes of Hamlet, the spectators remember her as one of the protagonists; plus, she is 
probably the one the audience sympathizes most with. Apart from the fact that she is "fair" and that she dies of drowning after having gone mad, Shakespeare leaves everything vague about her: his ambiguous text does not reveal whether her madness is due to her father's death or to her lover's repudiation, nor does it dispel any doubts concerning her willingness to put an end to her own life. She is a mere "nothing", a vacuum. By virtue of this absence, of this hollow space - categories to which women are often relegated in the patriarchal system of thought - multifarious interpretations of Ophelia have been found: in Shakespeare's own time, Ophelia was considered a gentle paradigm of erotomania or love-melancholy, while in the 1700s her part was often cut or censured due to the lewdness of her mad-songs, condemned as unsuitable and indecent. For this reason, in order to spiritualize the bawdy language with suave tunes, Ophelia's role was often interpreted by singers.

Coleridge - followed by many Romantic critics - believing Hamlet to be a hero who thought too much, considered Ophelia a heroine who felt too much, and Hazlitt even labelled her "a character almost too exquisitely touching to be dwelt upon” (Hazlitt 1817: 111). The French Symbolists, after Mallarmé and Rimbaud, were fascinated by the blanche Ophélia (Rimbaud 1895), as candid as a white page for male fantasy to write on. These poetic visions were undermined by twentieth century psychiatry, whereby Ophelia once again became the object of medical attention and was merely classified as insane in need of treatment; to borrow Laing's words (1960: $214 \mathrm{n} 1$ ): "Clinically she is latterly undoubtedly a schizophrenic. In her madness, there is no one there. [...] Incomprehensible statements are said by nothing. She has already died. There is now only a vacuum where there was once a person."

Being classified as illness, madness becomes rational, and logical, so it no longer terrifies the audience/reader. Still this did not stop Ophelia's subversive march, especially after her madness. In revolutionary theatre, she became the emblem of the victims' revolt. The contemporary reception of the Ophelia myth is in fact inevitably mediated by the influence of feminist critics who "promoted a new perspective on Ophelia's madness as protest and rebellion" (Showalter 1985: 91). It may suffice here to quote, as an example, two rewrites of Shakespeare's Hamlet where Ophelia is radically transformed: Heiner Müller's most controversial play, Hamletmaschine (1977) and Melissa Murray's agitprop play Ophelia (1979).

In Hamletmaschine, Ophelia is presented as Hamlet's counterpoint in an opposition between male and female universal, History and Myth, intellectual conniving with the predominant regime and victim of the same regime, and finally, crystallised classic Tragedy and a new experimental Theatre (Teraoka 1985: 97; Falchi 2010). 
As the play progresses, Ophelia proceeds from the Shakespearean victim of oppression - "the one the river didn't keep. The woman dangling from the rope. The woman with slit arteries. The woman with the overdose SNOW ON HER LIPS. The woman with the head in the gas oven" ${ }^{-}$to a vengeful, bloodthirsty, heroine when she screams: "Here speaks Electra" (Müller 1995 [1977]: 94). In Act 5 Ophelia appears defeated, re-inserted into the patriarchal logic and frozen in a tableau vivant: grotesquely bound by white muslin to a wheelchair, she is secluded in a mental hospital. However, the association with Electra hints at a return to the region of myth - and therefore to archetypal thinking where the opposites of reason and madness, single and community, society and nature, can finally merge beyond dualistic thinking (Hillman 1989). Therefore, in spite of her seclusion and immobilization, she appears not to surrender, but rather to speak directly to the audience's consciousness, communicating her anger and her revolutionary drive through the language of images. Looking to the degradation around her, she does not protest anymore: she becomes the manifesto of protest, an image that can throw into chaos the audience's scleroticised beliefs. Such an interpretation was particularly reinforced by the memorable 1987 performance of Hamletmaschine by the theatre group Carbone 14, at Le Festival de Théâtre des Amériques in Montreal (Knowles 2003 [1998]: 124-125). Ophelia, in one of her four costumes, appeared on stage in the guise of Marilyn Monroe in The Seven Year Itch provokingly conjuring up the victims of male abuse and institutional powerand her skirt blown by a current of air became the immediate metaphor for the unveiling of a dramatic, eroticized, truth. To borrow Jill MacDougall's words, "The performance is over - but not the doubt concerning reality. Maybe some in the audience, like Ophelia, have seen through the veils of representation" (MacDougall 1988: 18).

Another estranging heroine is the protagonist of Melissa Murray's Ophelia, the alternative, unpublished, retelling of Shakespeare's Hamlet written for Hormone Imbalance, an English theatre company which satirised lesbian stereotypes, sexual politics and prejudice (Dyer 2002: 23). Few accounts remain of their powerful 1979 London performance at Action Space. This staging offered a rewrite of Hamlet's story from the point of view of women, with the addition of a lesbian sub-plot: Ophelia falls in love with her maid and they run away to join a guerrilla commune (Wandor 1981: 47). Murray's blank verse Ophelia was hailed by feminist critic Michelene Wandor as a symbol

Excerpts of Hamletmaschine are cited from the English translation by Mark von Henning: Müller, H. 1995 [1977]. The Hamletmachine. - M. von Henning, ed. and trans., Theatremachine. London: Faber and Faber, 87-94. This quote is on p. 89. 
FALCHI

of the development of revolutionary theatre claiming that "theatre workers concerned with sexual politics are now dealing with poetry and elaborated language, and developing production styles to make their work accessible and challenging" (Wandor 1981: 47).

Women's movements have worked to change perspectives on the Ophelia myth and on the role of females in society, but "has that helped?" This question was central to Mary Pipher's influential book Reviving Ophelia (1994) and the subsequent 2005 play and 2011 Canadian movie of the same title - where the Shakespearean heroine is adopted as paradigm of deranged girls seeking guidance:

The story of Ophelia from Shakespeare's Hamlet shows the destructive forces that affect young women. As a young girl Ophelia is happy and free, but with adolescence she loses herself. When she falls in love with Hamlet, she lives only for his approval. She has no inner direction; rather, she struggles to meet the demands of Hamlet and her father. [...] When Hamlet spurns her because she is an obedient daughter, she goes mad with grief. (Pipher 1994: 20)

In her study, Pipher raises questions about how a media-driven culture distorts the expectations of pre-adolescent girls, leading them to "go down in droves. They crash and burn in a social and developmental Bermuda Triangle" (Pipher 1994: 19).

After the revolution she tried to lead in the Seventies, at the dawn of the third millennium, Ophelia becomes once again a symbol of defeated powerless women in search of guidance. How was this possible? How did it happen that the women who "seemed more and more determined to stand up and fight, to make themselves heard" (Dijkstra 1986: 63) appear nowadays to succumb to a new wave of misogyny and accept to be represented by means of the "weak witted, expiring woman” (Dijkstra 1986: 45)? The sociological and psychological implications of these questions - although challenging and fascinating - lie outside the scope of the present study which will instead focus on the Victorian origins of the cult of Ophelia, since this period marked a turning point in the development of the myth of the "sexless sacrificial virgin" (Dijkstra 1986: 63). Besides, it is now widely acknowledged that the influence of the literature and culture of the long nineteenth century on our contemporary culture surpasses by far what was previously thought, to the point that it is possible to talk about a so-called Victorianomania. Hence, it also becomes necessary to recognize the works of Pre-Raphaelite artists, especially Millais' Ophelia (1851-1852), as a 
key to the interpretation of recent representations of Ophelia - paradigmatic examples are Alfred Hitchcock's Vertigo, and Gregory Crewdson's digital C-print Untitled (Ophelia), 2000-20012.

As Dijkstra demonstrated in Idols of Perversity (1986), for the Pre-Raphaelites Ophelia embodied "the love-crazed self-sacrificial woman who [...] in the end committed herself to a watery grave, thereby fulfilling the nineteenthcentury male's fondest fantasies of female dependency" (Dijkstra 1986: 42). Yet, these masterpieces managed to convey ambiguous stimuli - with their power to represent both the victim and the fight against the victimization because they were created in a time where the issues of women rights and women power were beginning to be analyzed.

Thanks to the touching Pre-Raphaelite renditions of the unfortunate maid and to the tragic fate of Millais' model - the poet and painter Elizabeth Siddal after two centuries and after feminism, the representations of Ophelia are once again a symbol of desirable submission - imposed by a recrudescence of patriarchal thinking and misogyny ${ }^{3}$ - and at the same time of the debate around this issue.

\section{Victorian Ophelia}

At a time when the issues of women's rights, sexuality, purity, and guilt gradually became central to the development of art in general and literature in particular, very different interpretations of Ophelia titillated the Victorians. Significantly, during the long nineteenth century, Ophelia was the single most represented subject of English literary painting: at least fifty images were presented in exhibitions of the Royal Academy alone (Solomon Kiefer 2001: 12; Altick 1985: 299).

Victorian girls in literature and art were meant to have religious, angelic, and romantic connotations and their representations were often associated with flowers: girls were considered as blossoms that one day would turn into mature, fertile womanhood (Casteras 1987: 40). In this view, adolescence was to be regarded as the most dangerous phase in a girl's growth, because it marked the passage from the innocence of childhood to the experience of

2 Also Eugènia Balcells Ophelia (2001) and Mary Ellen Mark's Laurie in the Ward 81 Tub, Oregon State Hospital (1976) seem to point towards the same interpratation; for an indepth analisys see Solomon Kiefer's The Myth and Madness of Ophelia (2001: 11-39).

3 Everyday Sexism in the Third Millennium (Rambo Ronai, Zsembik, Feagin 2014) and Misogyny: The Male Malady (Gilmore 2001) investigate convincingly this never-extinguished problem. 
FALCHI

maturity. Ophelia was therefore to be pitied as an emblem of feminine qualities cast upon too young a girl, a creature too naive to survive the bleakness of life. In her then influential study Shakespeare's Heroines: Characteristics of Women Moral Poetical \& Historical (1832) Anna Jameson so explained the unfortunate girl's condition:

In Shakespeare "the feminine character appears resolved into its very elementary principles - as modesty, grace, tenderness. Without these, a woman is no woman. [...] Shakespeare has shown us that these elemental feminine qualities, $[\ldots]$ when thrown alone amid harsh and adverse destinies, and amid the trammels and corruptions of society, without energy to resist, or will to act, or strength to endure, the end must needs be desolation.

Ophelia - poor Ophelia! O far too soft, too good, too fair, to be cast among the briers of this working-day world, and fall and bleed upon the thorns of life" (Jameson 1904 [1832]: 110-112).

Subsequently, most of Ophelia's representations depicted her as a gracious girl, who, although deranged, did not lose her beauty or her proper countenance. The moments before her death were typically considered appropriate for Victorian standards, as ladies could draw from it a vital lesson on the dangers of abandoning themselves to their own passions, without being vexed by the view of her cruel fate; further, the anticipation of Ophelia's tragic ending would have perfectly satisfied the coveted desire for pathos.

Typical examples of Victorian Shakespearean illustrations are offered by the so called "keepsake albums" or "books of beauty" - collections of prose and verse adorned by engravings of young women in the guise of characters from literature. Charles Heath, who specialized in these publications, issued two volumes dedicated to Shakespeare's heroines: A Shakespeare Gallery Containing the Principal Female Characters in the Plays of the Great Poet (1836-1837) and Heroines of Shakespeare.

The conventionality of similar illustrations was despised by the PreRaphaelite Brothers, who aimed at fighting the triviality of such "trite and affected" (Holman-Hunt 1914: 34) subjects while pursuing a perfect imitation of nature. It is for these reasons that, in their representations of Ophelia, the attention to the details of the original text and of the setting proved vital.

In 1852 Millais and Hughes simultaneously presented their Ophelias at the Royal Academy. Strange as it may seem, Millais's painting, now regarded as an absolute masterpiece of English painting, was greeted coldly by its contemporary critics: 
The artist $[\ldots]$ has adhered most strictly to the letter of the text. Ophelia was drowned chanting snatches of old tunes, and she was "incapable of her own distress." Thus the picture fulfils the conditions of the prescription, but there are yet other conditions naturally inseparable from the situation, which are unfulfilled (AJ 1852: 174).

There must be something strangely perverse in an imagination which souses Ophelia in a weedy ditch, and robs the drowning struggle of that lovelorn maiden of all pathos and beauty, while it studies every petal of the darnel and anemone floating on the eddy (TA 1852: 581).

This welcoming can only be understood if one considers that Millais's Ophelia, to a Victorian eye, unmistakably hinted at an iconography not proper for a young girl: her open arms suggest mature sexuality, and so does the mermaidlike spreading of her robes. Moreover, the association with death by water, and suicide, was at the time a prerogative of the representation of fallen women, as shown by Thomas Hood's poem "The Bridge of Sighs”, which inspired many pictures, including George Frederic Watt's Found Drowned (1848-1850) and Millais's etching and engraving The Bridge of Sighs (1858).

It is to be remembered that, in the Victorian age, virginity and sexual promiscuity were regarded as two paradoxically closely related extremes, necessary for the preservation of society (Casteras 1987: 131). As a consequence, the fate of a fallen woman was often sentimentalised, mainly for the reason that a young woman was reputedly in danger of falling not only for greed but also for need, in which case she may be redeemed by repentance and reintegration into her family (Nochlin 1989 [1988]: 61). Ophelia's family, though, was unable to help - an absent mother, a dead father and her brother off to France - and she had to die unredeemed. This context underlies Millais' work, the portrait of an ethereal girl dying in the water, charged with the imagery of drowning falling women, which disrupted a long tradition of sweet deranged Ophelias.

The idyllic background wins over prejudice, with nature prevailing over guilt, while "Ophelia drifts with palms upturned, just breaking the surface of the water, offering herself to death. The face is that of a very young and innocent woman, with delicate ivory and rose skin, blue eyes, and blond brows and lashes. [...] The image is one of utter passivity" (Daly 1989: 41).

On the contrary, Arthur Hughes and J. W. Waterhouse opted for more traditional solutions: they sentimentalised their Ophelias, and dedicated particular attention to the nature surrounding her. For these reasons, Arthur Hughes's image provoked critical enthusiasm: 
FALCHI

A sweet, child-like face is Ophelia's, its look of vacancy scarcely dimming its beauty; the absence of reason developing itself rather in her actions, as she drops the white blossoms into the slowly-flowing stream, and watches them quietly floating away, than in her countenance. [...] The composition is, undoubtedly, that of an artist whose mind has thoroughly felt his subject, and given to it a truly poetical rendering (AJ 1865: 332).

J. W. Waterhouse located his mad Ophelias out of doors, suggesting "her innately female connection to nature, especially water, and acknowledg[ing] connections between her sexuality, grief and eventual death" (Rhodes 2008: 119). His Ophelias show an evolution both in the maturity of the subject and in her progress towards the fatal water. The young 1889 Ophelia, lying down on the grass and playing with the plants, hints at the perils of the passage from childish purity to sexual maturity; the madness generated by such a change is concentrated in her eyes, while the river streams at the back. Rather than focusing on her intense gaze, in 1894 Waterhouse's new Ophelia suggests distraction through her raised arms, while she sits by the water combing her hair. This picture did not appeal to contemporary critics, as it communicated "little of Ophelia's distress and not much of her pain and sorrow" (Stephens 1894: 620). Finally, the 1910 picture of Ophelia next to the water clearly expresses her grief and madness through her red cheeks and frenzied look; a bunch of flowers in her hands highlights her link to nature, and her extraneity to the social world is symbolized by the passersby who walk in the background unaware of her tragic destiny.

\section{Ut natura pictura (et poesis): Elizabeth E. Siddal as a Real Ophelia}

I lie among the tall green grass

That bends above my head [...]

Tenderly and lovingly

Like grass above the dead.

(E. Siddal, $A$ Year and $a$ Day $\left.{ }^{4}\right)$

Millais's choice to depict Ophelia in the instants preceding her death-immersed in nature and water - is possibly due to his aspiration to fulfil his ideal of perfect

4 Siddal's poems are quoted from the philologically accurate version proposed by Stefania Arcara in Arcara, S. 2009. Elizabeth Siddal. Di rivi e gigli. Bari: Palomar. 
imitation of nature and of the original text. Most of the flowers in the painting derive from the Shakespearean text, either from Gertrude's speech or Ophelia's erratic songs; those which do not are included in the painting because of their symbolic meaning, like the forget-me-nots, the pansies - for unrequited love -, and the poppy - the emblem of Sleep, brother of Death, and therefore of Ophelia's smooth passing away without suffering. However, this pacifying flower holds tremendously uncanny connotations when linked to the painting's model. The sitter for Millais's painting was in fact the Pre-Raphaelite stunner, painter and poet Elizabeth Siddal, wife to Dante Gabriel Rossetti. The two had a problematic relationship, marked by constant procrastinations of their wedding, her ill health, and his continuous betrayals, which were allegedly the reason behind her supposed suicide in 1862 due to an overdose of laudanum, a derivate of the poppy.

Rossetti developed, even before Siddal's death, a sense of guilt for her unhappiness, which provoked him to identify with Hamlet, the tragic prince who, by causing his beloved's death, also hastened his own end. Eventually, the thought of Siddal's death not being accidental - and of him being its possible cause - haunted him to depression and consequently to insomnia, chloral abuse and addiction to spirits (Doughty 1949: 550).

The identification between Elizabeth Siddal and Ophelia most certainly originated with Millais's painting, and was a commonplace among their circle. For Rossetti it became a source of inspiration for paintings and poems. In 1858 he drew in pen and black ink a representation of Act III, scene i. Some elements of this elaborate study seem to suggest that Rossetti considered Ophelia a cause of Hamlet's madness. The iconography resembles that of Gabriel's annunciation to the Virgin Mary, suggesting a parallel between Mary's absolute chastity and Ophelia's temptation. Ophelia does not respond to Hamlet's eager eyes, provoking his anxious look, and possibly his imminent madness.

"In the woodwork are symbols of rash introspection - the tree of knowledge, and the man who touched the ark and died" (Rossetti 2002-2010: 691). The tree marks the capital sin: the thirst for knowledge, the desire to be like the Creator. Ophelia sinned because she wanted to know if Hamlet ever loved her, and Siddal wanted to become a creator of art.

On the left is portrayed Uzza, the man who died because he touched the Ark in an attempt to prevent it from falling. This biblical story was often used in Victorian times to indicate that one should never disobey God's words, even if they believe they are doing something for the good. Ophelia's arm is in the same position as Uzza's, suggesting her mistaken sense of duty.

A sword of chastity divides the two characters, and a crucifix stands between them, comparing human sufferings with God's. Significantly, the 
FALCHI

Christ-like victim is here Hamlet, as his crucified position implies. The conversation between Hamlet and Ophelia - H.: "I loved you not" O.: "I was the most deceived" - is paralleled in two poems written, at around the same time, by D.G. Rossetti. In "A New-Year's Burden," the poet comments thus on the loss of love:

The branches cross above our eyes,

The skies are in a net:

And what's the thing beneath the skies

We two would most forget?

Not birth, my love, no, no, -

Not death, my love, no, no, -

The love once ours, but ours long hours ago.

To which Siddal's "Love and Hate" uncannily replies excluding any possibility of redemption:

Ope not thy lips, thou foolish one,

Nor turn to me thy face;

The blasts of heaven shall strike thee down

Ere I will give thee grace.

$[\ldots]$ thou art like the poisonous tree

That stole my life away.

After Siddal's death, Rossetti painted more Ophelias, with her features. Particularly haunting is the scene from Act IV, sc. $v$ in The First Madness of Ophelia (1864). There, as David Sonstroem in Rossetti and the Fair Lady explained (1970: 95-97), Ophelia appears as a pitiable, mad and disquieting young woman, with Laertes driving her out of view and Claudius and Gertrude looking at her as a "poor wretch". Her eyes look out of the canvas, accusing her own painter of driving her to madness.

Siddal/Ophelia's eyes become the symbol of Rossetti's curse in his ballad "An Old Song Ended" (1869 - just after the opening of Siddal's grave), where one of Ophelia's Shakespearean fragments is completed with images derived from the iconography of Siddal, like her famous hair which allegedly grew after her death to fill the grave, the death while true love was absent, and her haunting eyes: 
'How should I your true love know

From another one?'

'By his cockle-hat and staff

And his sandal-shoon.'

[... 'How may I, when he shall ask,

Tell him who lies there?'

'Nay, but leave my face unveiled

And unbound my hair.'

'Can you say to me some word

I shall say to him?'

'Say I'm looking in his eyes

Though my eyes are dim.'

\title{
4. Conclusion
}

The Shakespearean fair Ophelia has become through the centuries a "cubist Ophelia" (Showalter 1985: 92), a multifaceted heroine apt to embody all the victims of patriarchal domination, but also the victimized decadent lady, the Belle Dame Sans Merci, who would annihilate her tormentor. Similar oxymoronic identifications were possible partly because of the vagueness that distinguishes her character in the Shakespearean tragedy, and partly because of the fluctuating status of adolescent girls in society.

The development of this myth proved particularly tragic in Victorian times when issues about the condition, the power, and the rights of women were raised. It was no coincidence in this period that the poet and painter Elizabeth Siddal - model in Millais' influential portrait of Ophelia - came to be identified with the heroine in the collective imaginary, by virtue of her unquenchable thirst for knowledge, her unrequited love, and her sublime beauty.

\author{
Simonetta Falchi \\ sfalchi@uniss.it \\ Dipartimento di Scienze Umanistiche e Sociali \\ Università degli Studi di Sassari \\ Via Roma 151 \\ 07100 Sassari \\ ITALIA
}


FALCHI

\section{References}

AJ 1852 = Art-Journal. “The Royal Academy”, 14.

AJ $1865=$ Art-Journal. "Talbot and the Countess of Auvergne".

Altick, R.D. 1985. Paintings from Books: Art and Literature in Britain, 1760-1900.

Columbus (OH): Ohio State University Press.

Arcara, S. 2009. Elizabeth Siddal. Di rivi e gigli. Bari: Palomar.

Casteras, S. P. 1987. Images of Victorian Womanhood in English Art. Rutherford (NJ): Fairleigh Dickinson University Press.

Daly, G. 1989. Pre-Raphaelites in Love. New York: Ticknor \& Fields.

Dijkstra, B. 1986. Idols of Perversity: Fantasies of Feminine Evil in Fin-de-Siècle Culture. New York-Oxford: Oxford University Press.

Dyer, R. 2002. The Culture of Queers. London-New York: Routledge.

Doughty, O. 1949. A Victorian Romantic. Dante Gabriel Rossetti. London: Frederick Muller.

Falchi, S. 2010. "Maddening Endurance” Post-Modern Images of Ophelia’s Madness. Shakespeare en devenir. Folie et théâtralité, 3, 28.01 - http://shakespeare.edel.univpoitiers.fr/index.php?id=161 (19.11.12).

Gellert-Lyons, B. 1977. The Iconography of Ophelia. - ELH, 44, 1, Spring, Baltimore (MD): The Johns Hopkins University Press, 60-74.

Gilmore, D.D. 2001. Misogyny: The Male Malady. Philadelphia (PA): University of Pennsylvania Press.

Hazlitt, W. 1817. Characters of Shakespeare's Plays. London: C.H. Reynell.

Hillman, J. 1989. A Blue Fire: Selected Writings. T. Moore, ed., New York: Harper Perennial.

Holman-Hunt, W. 1914. Pre-Raphaelitism and the Pre-Raphaelite Brotherhood. Second Edition, vol. 1, New York: E.P. Dutton and Company.

Jameson, A. 1904 [1832]. Shakespeare's Heroines: Characteristics of Women Moral Poetical \& Historical. London: Dent.

Johnson, S. 1765. Notes. - W. Shakespeare, The Plays of William Shakespeare in Eight Volumes: With the Corrections and Illustrations of Various Commentators; to Which Are Added Notes by Sam Johnson. Vol. 8, London: J. and R. Tonson.

Knowles, R. 2003 [1998]. “The Real of It Would Be Awful:” Representing the Real Ophelia in Canada. - Shakespeare and Canada: Essays on Production, Translation, and Adaptation. Brussels: Peter Lang, 117-136 [Theatre Survey, 39, 1, May 1998, 21-40].

Laing, R.D. 1960. The Divided Self: A Study of Sanity and Madness. London: Tavistock Publications.

MacDougall, J. 1988. Le Festival de Théâtre des Amériques. Montreal 1987. - TDR, 32, 1, Spring, 9-19.

Müller, H. 1995 [1977]. The Hamletmachine. - M. von Henning, ed. and trans., Theatremachine. London: Faber and Faber, 87-94.

Nochlin, L. 1989 [1988]. Women, Art, and Power and Other Essays. London: Thames and Hudson. 
Re-mediating Ophelia with Pre-Raphaelite Eyes

Pipher, M. 1994. Reviving Ophelia: Saving the Selves of Adolescent Girls. New York: Putnam.

Rhodes, K. 2008. Ophelia and Victorian Visual Culture: Representing Body Politics in the Nineteenth Century. Aldershot: Ashgate.

Rimbaud, A. 1895. Ophélie [1870]. - Poésies Complètes. Avec préface de Paul Verlaine. Paris: Leon Vanier, 62-64.

Rambo Ronai, C., Zsembik, B.A., Feagin J.R. 2014. Everyday Sexism in the Third Millennium. New York-London: Routledge.

Rossetti, D. G. 2002-2010. The Correspondence of Dante Gabriel Rossetti. W.E. Fredeman, ed., vol. 2, Woodbridge: D.S. Brewer.

Showalter, E. 1985. Representing Ophelia: Women, Madness, and the Responsibilities of Feminist Criticism. - P. Parker, G. Hartman, eds., Shakespeare and the Question of Theory. New York-London: Methuen.

Solomon Kiefer, C. 2001. The Myth and Madness of Ophelia. - Amherst (MA): Mead Art Museum-Amherst College.

Sonstroem, D. 1970. Rossetti and the Fair Lady. Middletown (CT): Wesleyan University Press.

Stephens, F. G. 1894. The Athenaeum, 12 May, cit. in Trippi (2004: 135).

TA 1852 = The Athenaeum. "Fine Arts - the Royal Academy", 25.

Teraoka, A. A. 1985. The Silence of Entropy or Universal Discourse: The Postmodernist Poetics of Heiner Müller, New York-Berne-Frankfurt am Main: Peter Lang.

Trippi, P. 2004. J.W. Waterhouse. London: Phaidon.

Wandor, M. 1981. Understudies: Theatre and Sexual Politics. London: Eyre Methuen. 